\title{
Layanan Bimbingan Pra Nikah dalam Meningkatkan Kematangan Emosional Berkeluarga
}

\section{Nofiyanti}

\begin{abstract}
Abstrak
Pernikahan yang dilakukan ketika usia remaja, pasangan semestinya siap mengelola rumah tangga yang berarti menunjukkan kematangan emosi. Ketidakmampuan remaja untuk mengontrol emosi, membuat keputusankeputusan, dan memahami dirinya akan membuat kehidupan pernikahan yang dijalani kurang harmonis. Jika terjadi pernikahan, maka perlunya Bimbingan pra nikah agar dapat memperoleh kebahagiaan dalam kehidupan rumah tangga. Adapun tujuan dari penelitian ini adalah untuk mengetahui layanan bimbingan pra nikah dalam meningkatkan kematangan emosi yang dilakukan kepada calon pasangan yang menikah usia dibawah usia 16 tahun dan mengetahui hasil layanan bimbingan pra nikah yang dilakukan kepada calon pasangan yang menikah dibawah usia 16 tahun di Kantor Urusan Agama Kecamatan Babakan. Metode yang digunakan pada penelitian ini adalah penelitian kualitatif dengan pendekatan studi kasus, teknik pengumpulan data dengan menggunakan teknik wawancara, observasi, dan dokumentasi. Analisis data menggunakan model Milles dan Huberman yaitu dengan 1) reduksi data (data reduction) 2) paparan data (data display) dan 3) penarikan kesimpulan dan verifikasi (conclusion drawing/verifying). Berdasarkan hasil penelitian yang diperoleh bahwa proses bimbingan pra nikah dalam meningkatkan kematangan emosional berkeluarga pasangan yang menikah usia dibawah 16 tahun, dilaksanakan dengan memberikan bimbingan pribadi sosial dengan metode ceramah dan face to face.
\end{abstract}

Kata Kunci: Bimbingan, Pra-Nikah, Kematangan Emosi

\section{PENDAHULUAN}

Berdasarkan hasil penelitian wawancara dengan Kepala Kantor Urusan Agama (KUA) Kecamatan Babakan Menikah di usia dini seakan menjadi 'tren', dengan dalih berbekal rasa cinta dan kasih sayang membuat mereka yakin melangsungkan pernikahan dini. Tentunya bukan hanya berdalih cinta dan kasih sayang saja yang menjadi alasan menikah di usia dini, di antaranya minimnya ilmu pengetahuan, kepentingan ekonomi, tradisi nikah usia dini, dan keleluasaan melakukan hubungan seksual dikalangan pemuda pemudi. Biasanya pernikahan dini dilakukan oleh pasangan muda yang rata-rata umumnya dibawah 16 tahun dan disebabkan karena hamil di luar nikah. 
Berdasarkan hasil penelitian wawancara dengan Penyuluh Kantor Urusan Agama (KUA) Kecamatan Babakan Pendidikan pra nikah dalam situasi dan kondisi anak muda jaman sekarang itu sangat penting dalam pemberian materi pendidikan pra nikah. Agama Islam mengajarkan kepada pemeluknya untuk tidak tergesa-gesa dalam segala tindakannya. Akan tetapi, ada sesuatu yang justru Islam menganjurkan untuk bersegera dilakukan. Setidaknya ada lima perkara: mengubur jenazah, membayar hutang, menghidangkan jamuan untuk musafir yang berkunjung, bertaubat, dan menikah.

Pernikahan usia muda dikaitkan dengan usia pernikahan yang diperbolehkan oleh Undang - Undang Negara Indonesia. Batas usia perkawinan dalam Undang Undang Perkawinan Bab II pasal 7 ayat 1 menyebutkan bahwa perkawinan hanya diizinkan jika pihak laki-laki mencapai umur 19 (sembilan belas) tahun dan pihak perempuan sudah mencapai umur 16 (enam belas) tahun (UU No.01 Tahun 1974). Sesungguhnya batasan usia pernikahan yang normal, berdasarkan pernikahan usia sehat yang ditetapkan Badan Koordinasi Keluarga Berencana Nasional (BKKBN) adalah usia 25 tahun untuk laki-laki dan 21 tahun untuk perempuan. Usia menjadi kriteria dari syarat pernikahan, karena usia menunjukkan kematangan dari fungsi diri individu baik secara fisik, psikis dan sosial.

Menurut Hurlock, Kemajuan iptek yang sangat maju dan usia belum matang sudah cepat menikah misalnya usia anak dibawah 16 tahun ia sudah menikah. Menurut teori perkembangan ialah masa usia menikah adalah saat usia dewasa awal yaitu 20-40 tahun atau usia 18-40 tahun. Dengan kata lain, masa dewasa awal merupakan masa dimana seorang individu mulai mengemban tugas menikah dan membina keluarga. Hal ini sejalan dengan pendapat dari Havighurst yang menyatakan bahwa tugas perkembangan yang menjadi karakteristik masa dewasa awal adalah mulai memilih pasangan hidup dan mulain berkeluarga.

Kematangan emosi pada usia remaja dipengaruhi oleh berbagai faktor. Faktor yang berpengaruh pada remaja dapat ditinjau dari faktor internal dan faktor eksternal remaja. Senada dengan hal itu faktor-faktor yang mempengaruhi perkembangan kematangan emosi menurut Syamsu Yusuf L. N. ialah usia, sikap, dan perlakuan orang tua, serta kualitas interaksi sosial remaja. Remaja yang menikah dini rentan dengan permasalahan yang dapat mempengaruhi perkembangan kematangan emosi.

Bimbingan Pra Nikah khusus Muslim ini berkonsentrasi pada pembekalan ilmu bagi para muda dan mudi yang akan segera menikah atau sebagai bekal penambah ilmu saat mereka akan ke jenjang pernikahan nanti. Bimbingan ini menjadi sangat penting karena penikahan bukanlah bersatunya laki - laki dan perempuan saja, tapi lebih dari itu memiliki makna ibadah yang luar biasa besar pahalanya dan memiliki daya ubah dan daya gugah pelakunya.Bimbingan Pra Nikah yang diberikan ini tidak hanya dari sudut pandang Agama Islam tapi juga ilmu - ilmu pemberdayaan diri yang disesuaikan dengan perkembangan zaman. Materi meliputi seputar pernikahan, manajemen keuangan, mendidik anak dan lain sebagainya. 
Menurut Syubandono, Agar individu-individu memiliki persiapan mental dan fisik atau materiil dalam menaiki jenjang perkawinan dan agar keluarga (rumah tangga) memiliki persiapan daya tahan yang kuat dalam menghadapi goncangan goncangan dari pengaruh internal maupun eksternal. Maka perlulah adanya suatu usaha untuk memberikan pelayanan, bantuan atau pertolongan. Adapun tujuan akhirnya yakni agar dapat memperoleh kebahagiaan dalam kehidupan rumah tangga. Usaha tersebut dilakukan baik oleh perseorangan maupun dalam bentuk suatu badan.

Prosesi bimbingan pra-nikah diharapkan dapat memberi panduan dan jangan sampai hanya menjadi ritual semata pada akhirnya tidak memberikan manfaat. Banyak kasus di sekitar kita, baru beberapa saat menikah, lalu bercerai, mereka berpacaran bertahun-tahun, namun menikmati bulan madu hanya beberapa bulan. Pernikahan yang dilakukan dengan usia yang belum cukup matang dibawah 16 tahun akan mengakibatkan dampak yang akan ditimbulkan diantaranya sering terjadinya perselisihan antara suami dan isteri yang secara terus-menerus, masalah yang tidak cepat diselesaikan, bahkan bisa menimbulkan stres bahkan depresi.

Bimbingan pra-nikah sangatlah penting sebagai wahana membimbing dua orang yang berbeda karakter untuk saling berkomunikasi, belajar menyelesaikan masalah dan mengelola konflik. Keterampilan ini jelas-jelas sangat penting dalam perjalanan kehidupan rumah tangga mereka. Pasangan muda sangat membutuhkan konseling terutama untuk memperjelas harapan-harapan mereka pada pernikahannya dan memperkuat hubungan sebelum menikah.

Berdasarkan uraian diatas, maka penulis tertarik untuk medeskripsikan bagaimana proses bimbingan pra nikah dalam meningkatkan kemtangan emosional dalam berkeluarga bagi calon pasangan yang mneikah usia di bawah 16 tahun. Sehingga peneliti tertarik untuk mengangkat judul penelitian Layanan Bimbingan Pra Nikah Dalam Meningkatkan Kematangan Emosional Dalam Berkeluarga (Studi Kasus Pada Calon Pasangan Yang Menikah Usia Di Bawah 16 Tahun Di Kantor Urusan Agama (KUA) Kecamatan Babakan).

\section{PEMBAHASAN}

\section{A. Bimbingan Pra Nikah}

Bimbingan terjemahan dalam bahasa inggris yaitu "guidance", istilah "guidance" berasal dari akar kata "guide" yang berarti: 1) mrngarahkan (to direct), 2) memandu (to pilot), 3) mengelola (to manage), dan 4) menyetir (to steer). Selain itu "guidance" mempunyai hubungan dengan "guiding" yang berarti menunjukan jalan (showing a way), memimpin (leading), menuntun (conducting), memberikan petunjuk (giving intructions), mengatur (regulating), mengarahkan (governing) dan memberikan nasihat (giving advice). (M.Fuad Anwar, 2014:1-2).

Shertzer dan Stone menyatakan bahwa bimbingan sebagai " process of helping an individual to understand himself and his world." Bimbingan adalah 
proses pemberian bantuan kepada individu agar mampu memahami diri dan lingkungannya. (Yusuf L.N, Syamsu dan Juntika, 2006:29) Kartadinata,S., mengartikan bimbingan sebagai "proses membantu individu untuk mencapai perkembangan optimal. (Kartadinata, 2003:27). Berdasarkan uraian diatas bahwa yang dimaksud dengan bimbingan adalah proses membantu individu memahami diri sendiri dan dunia yang ada di sekitarnya.

Kata pra menurut Kamus Besar Bahasa Indonesia yaitu sebelum, didepan. (kbbi.kata.web.id/pra/) Nikah yaitu ikatan lahir batin seorang pria dengan seorang wanita sebagai suami dan istri untuk mentaati perintah Allah dan melaksanakan ibadah untuk membentuk keluarga yang bahagia dunia akhirat. Jadi dapat disimpulkan bahwa Bimbingan Pra Nikah ialah proses pemberian bantuan terhadap individu agar dalam menjalankan pernikahan dan kehidupan rumah tangga bisa selaras dengan ketentuan dan petunjuk Allah sehingga, dapat mencapai kebahagiaan hidup dunia dan akhirat.

Bimbingan pra nikah memang sangat di perlukan sebelum melakukan pernikahan, hal ini sejalan dengan hadist yang di riwayatkan oleh Abu Daud yaitu:

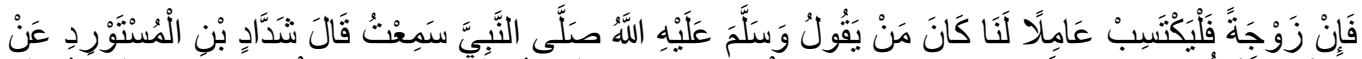

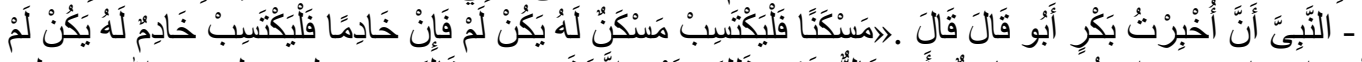

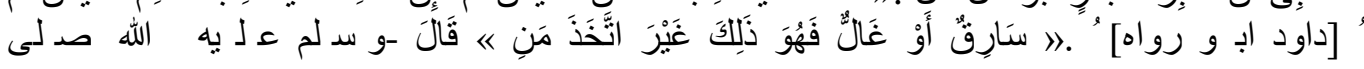

"Al Mustaurid bin Syaddad, ia berkata; saya mendengar Nabi shallallahu 'alaihi wasallam bersabda: "Barangsiapa yang menjadi pegawai kami maka hendaknya ia mencari seorang isteri, apabila ia tidak memiliki pembantu maka hendaknya ia mencari pembantu, dan apabila ia tidak memiliki tempat tinggal maka hendaknya ia mencari tempat tinggal!" Abu Bakr berkata; aku diberi khabar bahwa Nabi shallallahu 'alaihi wasallam berkata: "Barangsiapa yang mengambil selain itu, maka ia adalah pengkhianat atau pencuri."

Hadits di atas menjelaskan bahwa seseorang apabila ia telah mampu hendaknya ia dapat memanfaatkan hasil dari pekerjaannya tersebut untuk hal yang bermanfaat sesuai dengan yang ia butuhkan. Apabila ia belum menikah maka hendaknya ia menikah. Karena, menikah itu di anjurkan bagi orang yang ia telah memiliki kemampuan baik secara lahir maupun batin. Implikasi haditshadits di atas adalah, konselor hendaknya dapat memberikan layanan informasi kepada tentang anjuran untuk menikah terutama bagi klien yang telah memiliki kemampuan baik lahir maupun bathin. Bisa juga dengan memberikan layanan konseling perorangan apabila klien mengalami masalah terkait dengan kesiapan untuk menikah.

\section{B. Kematangan Emosi}

Kematangan emosi dapat dipahami dengan mengetahui pengertian istilah kematangan dan emosi terlebih dahulu. Istilah kematangan menurut Skinner 
(Endah Puspita Sari \& Sartini Nuryoto, 2002: 78), menunjukkan adanya proses menjadi matang. Menjadi matang berarti adanya usaha peningkatan dan perbaikan. Individu yang dianggap telah memenuhi persyaratan untuk disebut matang masih terus berkembang, sehingga pada tiap-tiap saat individu menunjukkan taraf kematangan yang berbeda antara waktu yang lalu dengan waktu mendatang.

Hurlock (2004: 213), mendefinisikan kematangan emosi sebagai tidak meledaknya emosi dihadapan orang lain melainkan menunggu saat dan tempat yang lebih tepat untuk mengungkapkan emosinya dengan cara-cara yang lebih dapat diterima. Senada dengan hal itu, Sartre (dalam Gusti A. S. dan Margareta M. S. P, 2010: 36-37), mengungkapkan bahwa kematangan emosi adalah keadaan individu yang tidak cepat terganggu oleh rangsangan yang bersifat emosional, baik dari dalam maupun dari luar individu, selain itu dengan kematangan emosi individu dapat bertindak dengan tepat dan wajar sesuai dengan situasi dan kondisi.

Kartono (dalam Gusti A. S. dan Margareta M. S. P, 2010: 36), mendefinisikan kematangan emosi sebagai suatu keadaan atau kondisi mencapai tingkat kedewasaan dari perkembangan emosional, oleh karena itu pribadi yang bersangkutan tidak lagi menampilkan pola emosional seperti pada masa kanakkanak. Individu yang telah mencapai kematangan emosi dapat mengendalikan emosinya. Lebih lanjut Davidoff (dalam Gusti A. S. dan Margareta M. S. P, 2010: 36-37), menjelaskan bahwa kematangan emosi merupakan kemampuan individu untuk dapat menggunakan emosinya dengan baik serta dapat menyalurkan emosinya pada hal-hal yang bermanfaat dan bukan menghilangkan emosi yang ada dalam dirinya.

Kesimpulan dari banyak definisi di atas bahwa seseorang yang mempunyai kematangan emosi adalah orang yang telah mencapai tingkat kedewasaan dari perkembangan emosionalnya, menunjukkan emosi yang stabil tidak meledakledak, mampu mengendalikan atau mengontrol emosi dan mewujudkannya melalui respon emosional yang baik dan bertanggung jawab serta mengantisipasi secara kritis situasi yang dihadapi.

\section{Ciri-ciri Kematangan Emosi}

Salah satu perkembangan remaja dalam aspek emosi adalah memiliki kematangan emosi. Kematangan emosi pada remaja dapat dilihat dalam perilaku yang ditampilkan remaja. Walgito (2004: 43), memaparkan bahwa remaja yang matang emosinya memiliki ciri-ciri yaitu:

1. Dapat menerima keadaan dirinya maupun orang lain dengan objektif.

2. Pada umumnya remaja tidak bersifat impulsif, dapat mengatur pikirannya dalam memberikan tanggapan terhadap stimulus yang mengenainya. 
3. Dapat mengontrol emosinya dengan baik dan dapat mengontrol ekspresi emosinya walaupun dalam keadaan marah dan kemarahan itu tidak ditampakkan keluar.

4. Dapat berpikir objektif sehingga lebih bersifat sabar, penuh pengertian, dan cukup mempunyai toleransi yang baik.

5. Remaja memiliki tanggung jawab, dapat berdiri sendiri, tidak mengalami frustrasi, dan mampu menghadapi masalah dengan penuh pengertian.

Senada dengan pendapat Walgito di atas, Jersild (dalam Gusti A. S. dan Margareta M. S. P, 2010: 37-38), menjelaskan ciri-ciri individu yang memiliki kematangan emosi, antara lain:

1. Penerimaan diri yang baik

Remaja yang memiliki kematangan emosi dapat menerima kondisi dirinya dengan baik. Penerimaan diri pada remaja dapat dilihat dari segi fisik maupun psikisnya, baik secara pribadi maupun secara sosial.

2. Kemampuan dalam mengontrol emosi

Remaja yang matang emosinya memiliki kemampuan mengendalikan emosinya. Dorongan yang muncul dalam diri remaja untuk melakukan sesuatu yang bertentangan dengan nilai-nilai yang berlaku dapat dikendalikan dan diorganisasikan ke arah yang baik.

\section{Objektif}

Remaja yang memiliki kematangan emosi dapat memandang kejadian berdasarkan dunia orang lain dan tidak hanya dari sudut pandang pribadi. Remaja memandang setiap respon emosional yang berasal dari lingkungannya dengan objektif.

\section{Karakteristik Perkembangan Kematangan Emosi Remaja}

Masa remaja merupakan masa peralihan antara masa anak-anak ke masa dewasa. Pada masa ini, remaja mengalami perkembangan mencapai kematangan fisik, mental, sosial, dan emosional. Umumnya, masa ini berlangsung sekitar umur 13 tahun sampai umur 18 tahun, yaitu masa anak duduk di bangku sekolah menengah. Masa ini biasanya dirasakan sebagai masa sulit, baik bagi remaja sendiri maupun bagi keluarga atau lingkungannya.

Conny Semiawan (1989) mengibaratkan: terlalu besar untuk serbet, terlalu kecil untuk taplak meja karena sudah bukan anak-anak lagi, tetapi juga belum dewasa. Masa remaja biasanya memiliki energi yang besar, emosi berkobarkobar, sedangkan pengendalian diri belum sempurna. Remaja juga sering mengalamiperasaan tidak aman, tidak tenang, dan khawatir kesepian. Secara garis besar, masa remaja dapat dibagi ke dalam empat periode, yaitu:

1. Periode Pra Remaja (13 Tahun)

Selama periode ini terjadi gejala-gejala yang hampir sama antar remaja pria maupun wanita. Perubahan fisik belum nampak jelas, tetapi pada remaja putri biasanya memperlihatkan penambahan berat badan yang cepat sehingga mereka 
merasa gemuk. Gerakan-gerakan mereka mulai menjadi kaku. Perubahan ini disertai sifat kepekaan terhadap rangsangan dari luar dan respons mereka biasanya berlebihan sehingga mereka mudah tersinggungdan cengeng, tetapi juga cepat merasa senang atau bahkan meledak-ledak.

2. Periode Remaja Awal (14-15 Tahun)

Selama periode ini perkembangan fisik yang semakin tampak adalah perubahan fungsi alat kelamin. Karena perubahan alat kelamin semakin nyata, remaja seringkali mengalami kesukaran dalam menyesuaikan diri dengan perubahan-perubahan itu. Akibatnya, tidak jarang mereka cenderung menyendiri sehingga merasa terasing, kurang perhatian dari orang lain, atau bahkan merasa tidak ada orang yang mau memperdulikannya. Kontrol terhadap dirinya bertambah sulit dan mereka cepat marah dengan cara-cara yang kurang wajar untuk meyakinkan dunia sekitarnya. Perilaku seperti ini sesungguhnya terjadi karena adanya kecemasan terhadap dirinya sendiri sehingga muncul dalam reaksi yang kadang-kadang tidak wajar.

3. Periode Remaja Tengah (16-18 Tahun)

Tanggung jawab hidup yang harus semakin ditingkatkan oleh remaja, yaitu mampu memikul sendiri juga menjadi masalah tersendiri bagi mereka. Karena tuntutan peningkatan tanggung jawab tidak hanya datang dari orang tua atau anggota keluarganya tetapi juga dari masyarakat sekitarnya. Tidak jarang masyarakat juga menjadi masalah bagi remaja. Melihat fenomena yang sering terjadi dalam masyarakat yang seringkali juga menunjukan adanya kontradiksi dengan nilai-nilai moral yang mereka ketahui, tidak jarang remaja mulai meragukan tentang apa yang disebut baik atau buruk. Akibatnya, remaja seringkali ingin membentuk nilai-nilai mereka sendiri yang mereka anggap benar, baik, dan pantas untuk dikembangkan dikalangan mereka sendiri. Lebihlebih jika orang tau atau orang dewasa disekitarnya ingin memaksakan nilqinilainya agar dipatuhi oleh remaja tanpa disertai dengan alasan yang masuk akal menurut mereka.

4. Periode Remaja Akhir (19-21 Tahun)

Selama periode ini remaja mulai memandang dirinya sebagai orang dewasa dan mulai mampu menunujukan pemikiran, sikap, perilaku yang semakin dewasa. Oleh sebab itu, orang tua dan masyarakat mulai memberikan kepercayaan yang selayaknya kepada mereka. Interaksi dengan orang tau juga menjadi lebih bagus dan lancar karena mereka sudah memiliki kebebasan penuh serta emosinya pun mulai stabil. Pilihan arah hidup sudah semakin jelas dan mulai mampu mengambil pilihan dan keputusan tentang arah hidupnya secara bijaksana meskipun belum bisa secara penuh. Mereka juga memilih cara-cara hidup yang dapat dipertanggung jawabkan terhadap dirinya sendiri, orang tua dan masyarakat. (Mohammad Ali, 2015:67-69) 


\section{E. Dampak Pernikahan Di Bawah 16 Tahun Secara Psikologis}

Remaja yang melakukan pernikahan dini karena kehamilan yang tidak diinginkan biasanya secara psikologis merasa shock, marah, malu, ingin menolak, takut dan was-was. Selain itu pernikahan dini juga menimbulkan berbagai penyesalan bagi remaja. Penyesalan remaja terkait dengan masalah terputusnya studi, tidak dapat mencari penghasilan, ketidakmampuan diri dalam mengasuh anak-anak dan tidak memperoleh kesempatan untuk bergaul dengan orang-orang di luar komunitasnya.

Indaswari (dalam Syafiq Hasyim, 1999: 143-144), menyebutkan bahwa dampak pernikahan dini ialah: (1) pertengkaran dan percekcokan yang disebabkan oleh emosi masing-masing yang belum stabil; (2) mengakibatkan perceraian, meski akhirnya menikah lagi; (3) sangat terkait dengan masalah kesehatan seksual dan kesehatan reproduksi bagi remaja; (4) telah menghilangkan kesempatan untuk menempuh pendidikan yang lebih tinggi.

Menurut Aditya Dwi Hanggara (2010, 15-16), dalam penelitiannya menyebutkan bahwa dampak pernikahan dini antara lain: (1) menurunnya kualitas pendidikan; (2) munculnya kelompok pengangguran baru; (3) munculnya perceraian dini; (4) tingkat kesehatan ibu dan gizi anak kurang. Berdasarkan pemaparan di atas dapat disimpulkan bahwa pernikahan dini memiliki dampak yaitu, Pernikahan dini merupakan pilihan yang sulit bagi remaja putri, menimbulkan pertengkaran, dan terjadinya perceraian. Selain itu, dampak pernikahan dini pada remaja dapat memunculkan kelompok pengangguran baru, rendahnya tingkat kesehatan ibu dan anak, serta menghilangkan kesempatan bagi remaja untuk menempuh pendidikan yang lebih tinggi.

\section{F. Pernikahan Di Bawah 16 Tahun Dalam Perspektif Psikologi}

Casmini (2002: 52-54) mengemukakan bahwa pernikahan dini dalam psikologi bukan sekedar batasan usia pada remaja. Pernikahan dini lebih terkait dengan perkembangan non-fisik, baik perkembangan biologis maupun perkembangan psikologis (emosi dan sosial). Pernikahan dini berkaitan dengan perkembangan biologis, bahwa organ seks remaja mencapai ukuran matang pada akhir masa remaja, kira-kira menginjak usia 21 tahun atau 22 tahun. Pernikahan yang dilakukan pada usia belasan tahun bukan merupakan masa reproduksi yang sehat, karena organ seks belum mengalami kematangan.

Sementara itu, pernikahan dibawah 16 tahun berkaitan dengan emosi menunjukkan bahwa pada saat usia remaja terjadi ketegangan emosi meninggi akibat dari perubahan fisik dan kelenjar. Remaja juga mengalami masa remaja yang dipersingkat dengan melakukan pernikahan dini. Sehingga tugas dan perkembangan remaja juga mengalami perubahan termasuk dalam hal emosi.

Selain itu ditinjau dari psikologi, pernikahan dini berkaitan dengan aspek sosial bahwa remaja saat memasuki pernikahan memiliki kelompok sosial baru yang berbeda dengan sebelum remaja melakukan pernikahan. Perubahan 
kelompok sosial membutuhkan penyesuaian pada remaja. Di dalam penelitian ini, kematangan emosi pada remaja yang menikah dini merupakan bidang Bimbingan dan Konseling pribadi sosial.

\section{METODE PENELITIAN}

Kualitatif berarti sesuatu yang berkaitan dengan aspek kualitas, nilai atau makna hanya dapat diungkapkan dan dijelaskan melalui linguistik, bahasa atau kata-kata (Gunawan, 2015:82). Penelitian kualitatif menurut Bogdan \& Taylor adalah prosedur penelitian yang mengahsilkan data deskripsi berupa kata-kata tertulis atau lisan dari orang-orang dan berperilaku yang dapat diamati yang diarahkkan pada latar dan individu secara utuh.

Metode kualitatif ini lebih tepat digunakan untuk penelitian penulis, karena data yang diteliti berupa kata-kata tertulis atau lisan bukan menggunakan hitungan. Sehingga peneliti ini harapkan dapat mendeskripsikan dan menjelsakan secara mendalam mengenai perubahan mental anak bermasalah hukum pidana tindak asusila setelah melaksankannya bimbingan pra nikah di Kantor Urusan Agama (KUA) Kecamatan Babakan. Jenis penelitian ini yaitu penelitian kualitatif studi kasus, pendekatan studi kasus ialah pendekatan yang dilakukan secara intensif, terperinci dan mendalam terhadap suatu organisme (individu), lembaga atau gejala tertentu dengan daerah atau subjek yang sempit (Arikunto, 2000:116).

Alasan peneliti menggunakan teknik ini peneliti untuk mendeskripsikan mengenai kematangan emosi pasangan yang menikah usia di bawah 16 tahun, dengan memberikan layanan bimbingan pra nikah yang diberikan oleh penyuluh di KUA Desa Babakangebang. Pengumpulan data dalam penelitian studi kasus berupaya menelaah sebanyak mungkin data mengenai subjek yang diteliti. Mereka sering menggunakan berbagai metode: wawancara (riwayat hidup), pengamatan, penelaahan dokumen, hasil survei, dan data apapun untuk menguraikan suatu kasus secara terinci. (Mulyana, 2006: 201).

\section{HASIL PENELITIAN}

Dari hasil penelitian ini bahwa Layanan Bimbingan Pra Nikah Dalam Meningkatkan Kematangan Emosional Dalam Berkeluarga (Studi Kasus Calon Pasangan Yang Menikah Usia Di Bawah 16 Tahun Di Kantor Urusan Agama (KUA) Kecamatan Babakan) bahwa:

\section{A. Layanan Bimbingan Pra Nikah di KUA Kecamatan Babakan untuk} Meningkatkan Kematangan Emosional Berkeluarga

1. Pelaksanaan Bimbingan Mental

Bahwa pelaksanaan bimbingan pra nikah harus mengikuti prosedur yang telah ditetapkann serta secara bertahap serta bimbingan pribadi sosial bagi pasangan yang menikah dibawah umur.

2. Metode Layanan Bimbingan Pra Nikah 
Bahwa metode bimbingan pra nikah di KUA Kecamatan Babakan ada dua yang digunakan yaitu metode ceramah dan memberikan bimbingan pribadi sosial adapun pengertian bimbingan pribadi sosial berarti upaya untuk membantu individu dalam menghadapi keadaan batinnya sendiri dan mengatasi konflik-konflik dalam diri dalam upaya mengatur dirinya sendiri di bidang kerohanian, perawatan jasmani, pengisian waktu luang, penyaluran nafsu seksual dan sebagainya, serta upaya membantu individu dalam membina hubungan sosial di berbagai lingkungan, pergaulan sosial (Yusuf, 2007: 55).

Bidang Bimbingan pribadi sosial, sesuai dengan karakteristik individu pada usia remaja. Pada usia remaja individu mengalami banyak konflik, baik yang menyangkut masalah pribadi maupun sosial sehingga remaja harus dapat menyelesaikan permasalahan yang muncul. Kematangan emosi pada remaja yang dihadapkan pada kondisi pernikahan berbeda dengan remaja yang belum menikah. Remaja yang menikah dini harus menghadapi lingkungan dan permasalahan yang berbeda dari sebelum remaja menikah. Remaja yang melakukan penyesuaian dalam pernikahan dapat memiliki kematangan emosi.

3. Materi Layanan Bimbingan Pra Nikah

Dalam bimbingan pra nikah ialah materi Penyuluhan KB dan Imunisasi TT, materi UU Perkawinan dan Munakahat, materi Keluarga Sakinah, materi Kesehatan Reproduksi dan Kesehatan Ibu Hamil, dan materi Keluarga Sejahtera. 4. Pendekatan Layanan Bimbingan Pra Nikah Yang Di Berikan Kepada Calon Pasangan Yang Menikah Di Bawah 16 Tahun

Bahwa pendekatan yang digunakan dalam bimbingan pra nikah yang diberikan kepada calon pasangan yang menikah dibawah usia 16 tahun ialah pendekatan individual. Pendekatan individual adalah pendekatan ini pemberian bimbingan dan penyuluhan dilakukan dengan hubungan yang bersifat face to face relationship (hubungan empat mata) (Bimo Walgito, 1995:09).

5. Penerapan Layanan Bimbingan Pra Nikah Untuk Meningkatkan Kematangan

Emosional Dalam Berkeluarga Pada Calon Pasangan yang Menikah dibawah 16 tahun

Dengan memberikan bimbingan yang ekstra yaitu dengan memberikan bimbingan pribadi sosial kepada calon pasangan yang menikah duibawah 16 tahun dapat meningkatkan kematangan emosional dalam berkeluarga. Bimbingan pribadi sosial dapat memberikan gambaran hidup setelah berkeluarga.

\section{B. Hasil Layanan Bimbingan Pra Nikah yang Di Laksanakan Di KUA Kecamatan Babakan untuk Meningkatkan Kematangan Emosional Berkeluarga}

Dari ketiga kasus dan hasil wawancara diatas dapat disimpulkan bahwa Layanan Bimbingan Pra Nikah yang sudah di lakukan di KUA Kecamatan Babakan Dalam Meningkatkan Kematangan Emosional dalam Berkeluarga 
berhasil meningkatkan kematangan emosional dalam berkeluarga calon pasangan yang menikah usia dibawah 16 tahun dalam berkeluarga serta kasuskasusnya terjadi satu tahun yang lalu yaitu tahun 2017. Menikah di usia yang belum matang berpengaruh dalam kehidupan berumah tangga akan tetapi ada usaha yang dapat dilakukan dalam meningkatkan kematangan emosional dalam berkeluarga. Usaha tersebut dilakukan baik oleh perseorangan maupun dalam bentuk suatu badan lembaga.

\section{DAFTAR PUSTAKA}

Aditya Dwi Hanggara. (2010). Studi Kasus Pengaruh Budaya terhadap Maraknya Pernikahan Dini di Kecamatan Gejugjati Pasuruan. Skripsi. Universitas Negeri Malang

Al-Imam Taqi al-Din Abi Bakr bin Muhammad al-Husaini al-Damsyiqi al-Syafi'i. tanpa tahun. Kifayah al-Akhyar fi HalliGhayat al-Ikhtishar. Semarang: Usaha Keluarga

Al-Jaziri, Abdurrahman. (1986). Al-Fiqh 'ala Madzahib al-Arba'ah. Beirut: Dar alFikr

Anggia Kargenti Evanurul Marettih. (2009). Hubungan antara Penerimaan Perkembangan Fisik dengan Kematangan Emosi Remaja. Jurnal Psikologi (Volume 5 Nomor 1). Hlm. 70-81

Arikunto. (2000). Manajemen Penelitian, Jakarta: PT Rineka Cipta

Az-Zahrani, Musfir bin Said. (2005). Konseling Teraphy, Jakarta: Gema Insani

Bimo Walgito. (1995). Bimbingan dan Konseling Perkawinan, Yogyakarta: Andi Offset.

Offset. Ed II

Bungin, Burhan. (2010). Penelitian Kualitatif (Kominikasi, Ekonomi, Kebijakan Publik, dan Ilmu Sosial), Jakarta: Kencana

Grafindo Persada

(2012). Analisis Data Penelitian Kualitatif, Jakarta: Raja

Burhan Bungin. (2007). Penelitian Kualitatif Edisi Kedua, Jakarta: Kencana Prenada Media Grup

Casmini. (2002). Pernikahan Dini (Perspektif Psikologi dan Agama). Jurnal Aplikasi Ilmu-ilmu Agama (Volume III Nomor 1)

Chaplin, J.P. (2008). Kamus Lengkap Psikologi. Jakarta: PT Raja Grafindo.

Deddy Mulyana. (2010). Metodologi Penelitian Kualitatif (Paradigma Baru Ilmu Komunikasi dan IlmuSosial Lainnya), Bandung: PT. Remaja Rosdakarya

Gunawan, Imam. (2015). Metodologi penelitian kualitatif teori dan praktek, Jakarta: PT Bumi Aksara 
Hasan, Aliah Purwakania. (2006). Psikologi Perkembangan Islami (Menyingkap Rentang Kehidupan Manusia Dari Prakelahiran Hingga Pascakematian), Jakarta: PT Raja Grafindo Persada

Hurlock E. B. (1997). Psikologi Perkembangan: Suatu Pendekatan Sepanjang Rentang Kehidupan. Jakarta: Erlangga. . (1980). Psikologi Perkembangan. Jakarta: Erlangga

(1999). Psikologi Perkembangan Suatu Pendekatan Sepanjang Rentang Kehidupan. Jakarta: Penerbit Erlangga

Idrus Muhammad (2009). Metode Penelitian Ilmu Sosial. Yokyakarta: Erlangga Kamal, Mukhtar. (1974). Asas-asasHukum Islam TentangPerkawinan. Jakarta: Bulan Bintang

Lexy J. Meleong. (1994). Metodologi Penelitian Kualitataif. Bandung: PT. Rosdakarya . (2003). Metode Penelitian Kualitatif. Bandung: Remaja Rosda Karya

Karya

Mohammad Ali, Mohammmad Asrori. (2015). Psikologi Remaja. Jakarta: PT Bumi Aksara

Rofiq, Arif Ainur. (2005). Sistematika Psikologi Perkembangan, Surabaya: ARLOKA

Santrock, John W. (2007). Remaja: Ed 11 Jilid 1. Jakarta: Erlangga.

Sarwono, S. W. (2011). Psikologi sosial, individu dan Teori-teori Psikologi Sosial. Jakarta: Balai Pustaka.

Sitti Hartinah. (2008). Pengembangan Peserta Didik. Bandung: PT Refika Aditama Subagyo, Suprayogi, Sunarto Dkk. (2006). Pendidikan Kewarganegaraaan, Semarang: UPT Unnes Press

Sudarsono. (1997). Hukum Keluarga Nasional. Jakarta: Rineka Cipta

Sugiyono. (2005). Memahami Penelitian Kualitatif. Bandung: Alfa Beta

Suharsimi Arikunto. (2002). Prosedur Penelitian Suatu Pendekatan Praktek. Jakarta: Rineka Cipta

Sunarto. (2002). Perkembangan Peserta Didik. Jakarta: PT Rineka Cipta

Syafiq Hasyim. (1999). Menakar Harga Perempuan. Bandung: Mizan.

Syamsu Yusuf L. N. (2006). Psikologi Perkembangan Anak dan Remaja. Bandung: PT. Remaja Rosdakarya.

(2009). Program Bimbingan dan Konseling di Sekolah.

Bandung: Rizki Press.

Syamsudin, A. (2004). Psikologi Kependidikan. Bandung: Rosdakarya

Syubandono, Ahmad Hamdany. (1981). Pokok-Pokok Pengertian Dan Metode Penasehatan Perkawinan "Marriage Counseling"

Walgito Bimo. (2004). Bimbingan Dan Konseling Perkawinan. Yogyakarta: Andi Offse 
Yusuf, S. (2007). Psikologi Perkembangan Anak dan Remaja. Bandung: PT. Remaja Rosdakarya.

Zulkifli L. (2006). Psikologi Perkembangan. Bandung: PT Remaja Rosdakarya

(https://catatanuni.wordpress.com/2014/12/05/hadits-hadits-tentang-bimbingankonseling-pernikahan-dan-keluarga-islami/, diunduh tanggal 25 Agustus 2018 pukul 15.15 WIB)

(https://dalamislam.com/hukum-islam/pernikahan/ayat-pernikahan-dalamislam,diunduh tanggal 25 Agustus 2018 pukul $15.00 \mathrm{WIB}$ )

Herina. (1991). KematanganEmosi.(www.kematanganemosipikirdong.com,diakses Desember 2017)

(panduanskripsi.com/teknik-teknik-dalam-menetukan-sampel-penelitian-skripsi) 
Prophetic Vol. I, No. I, November 2018 